\title{
THE INDIVIDUAL WELFARE FUNCTION OF INCONE
}

\author{
A Lognormal Distrihution Function? \\ Burend IVIERENG $\wedge^{*}$

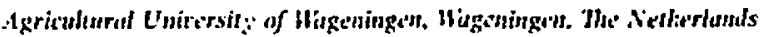 \\ Received Oclutuer 1977, find setsion teceived April 197s
}

\begin{abstract}
The procedure used by Yian Praas and Kippleyn to test the lleory that the individual wellare [unction of inconse is a lognormis distribution function is eritically eraluated. It is shosin th. 1 random datia giste the sume test results as tite income lesels actually collecied from real consumers. Thus it is doubilul wherlier V'on I'raje and Kapteyn's tesulss, even although they die based on data collecied from as many as 12000 cunsumers, protide any support for the lognormal model. It is conchuded that more pouerful methods are requifed io test the lognotmal model thoroughty.
\end{abstract}

\section{Introductions}

Van Praag (1968) has developed a wery ingenious theory with the major implication that the individual welfare function is a lognormal distribution funclion lin this article this is further to be referred to as the lognormal model). Using this model a number of interesting questions can be answered, such is:

- If person $A$ s welfare function of incone is a certa:i amount lower than that of person B. how much higher should $A$ 's incom: be if $A$ and $B$ are to share the same welfare level?

- If a fandily is to be kept al the same welfare level, how much incone compensation should it receive: as the family size increases?

Vau Praalg and Kapleyn (1973) discuss these and other applications of the mudel.

After the theory had been developed, Vall Praag and Kapleyn collected income evalualion data from \& different samples of consumers in Belgium and the Netherlands (more thaj 12000 persons in total) for an empirical test of the lognormal model. rwo reports on this research appeatred in this Journal: Van Praag (1971) and Van Prajg and Kapleyn (1973); a comprehensive presemtation of results is given in Kapteyn's recent dissertation 11977,

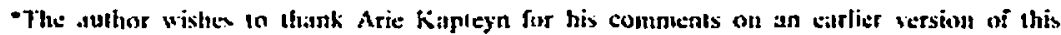

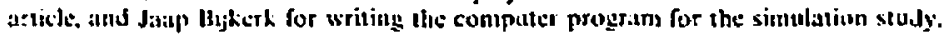


ch. IIl). On the basis of the rery goud fit of :lte model in this iest. for all eases, the authors concluded that the shape of the individual welfare function is approximattely lognormal.

Unfortunately however. from a simulation study it appears that income datat randomly drawn by a computer. withou any income evaluation notion. produce a fil to ihe lognormat moded in Viln Praag and Kapley'lis test linat is as guod as the fit obtained lor the inconic evaluation data collected from real consumers. The implicasticn is that the empirical dala used in Van Pralag and Kapteyn's researdl. althugh perlaps interesting in themselves. constitule little if a::y support for lla lognormal mu:lel.

This article describes the simulation study and its resulis. discusstes the major weikness in Vall Prailg and Kalpleyn's lesing procedure, and also suggests some more nowerful ways di lesting the lognormal model.

\section{Van l'ratag and Kiapteytis testing procedurc}

The melhods of data collection and antalysis are fully described by Kapleyn (1977. 月p. 59-721. They are summariad brichy here. Respondents in a sample of comstumers were askel to provide actual valuses lin 13frs. or Dn. respectively) for cight incoms luels. glatialively described in a questionnaire. The first level was the inconit level above whicl the consumer would est his income excellem": the second level was the income level above which the income woubd tec called "good". and so on. The lowest level was that below which the responden would call his income very bad". The complete list of athalifications in the questionnistre wits: "excellent. "gond".

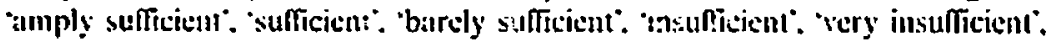
bad" and rerg batt. Vau Praan and Kapteyn assumed that a consumer would supply salues for these eight jucome lescls in such a way that the corresponding incone intervals soulc corresponc to equal quantities of his welfare function. Given this assumplion and lac lognornal distribution hypothesis. for the eight income levels of al particu:ar consumer.

$$
\ln y_{i}=\mu+\pi w_{j} . \quad i=1 \ldots . . . s .
$$

Here $y_{1}$ to $y_{4}$ are from fox to highly the inconte ievels niven by the responderit and $w_{1}$ lo $n_{4}$ are the points of the normal distribution with $p$ levels: \$\$.9" ". $77.8 " \ldots . . .11 .1$ ".. resputively. The patramelers of the normal distribution. $\mu$ and $\sigma$, are 10 be esimated. By applying? least ipuares to eq. (1). $\mu$ and $\sigma$ can be found and the fit of the tognurmal model can to: estimaled for every individual consumer. ]he tinivcrsal good fil [llte average multiple sorrelation coefticient $R$ (unsyuared) rang-ud from 0.97 10 0.98$]$ led Van Praing and Kanteyn wo conclede that these results supported the logusurmat! model. 
Now it is clear that with this dala collection procedure one will get from every respondem a series of eight increasing income levels (looked upen from "very' bad" upwarcis: the respondent provides then: in reverse order). The presumption is then that wheller or not they reflect the income staluation of the respondent in the way expected by Van Prata and kiapleyn. almost all of stuch series of income levels will cotrelate strongly with the series $w_{1}$ to $w_{k}$ (which also increatses monotonically). This was examined in the simulation study described in the next section.

\section{The simulation study}

In this study the co:mputer generated pseudo-respondents each with eight differelll income levels. These income levels were drawn randomly from the range Dn. $15000-500(0$. Afler rearranging them in increasing order, these income datal were an:lysed in the same way as Van Pratag and Kapteyn analysed lleir income evaluation data from real consanters.

The incense levels generated were runuled of 10 mulliples of DN. 1000. We stipulated lhat successive income levels should be at least DR. 1000 apart: thus if two intome lesels happened 10 coincide. one of them was increised by DI. 100\%.

The limits for the incone interval were determined as follows. WV wanted to compare the simulation results wilh the restults of Vall Prajeg and Kinpleyn's most recent studies for the Netlierlands ithich refer (1) 1974 and 1975. The lower limit of flue income range (DA. 15000) approxienittes to the 1974:75 net income level (affer tax and social security deductions) of a family with two children. earnıg the government-imposcd minimum wage. The upper limit (DA. 5U0Ui)) approximates to the 1974.75 net itcome level of a Dutcl governmen! ofijcial falso (wo children) being paid according to the highest rank in the entciatly published government salary scales. Thus in 1974,75 there were few fantiles caruing Jess than Dn. 15000 or more than Dn. imenu,.'

In Van Pralag and Kinjteyns data not erery respondent provided values for all cight incume levels requesled. Accordingly. for every pieudo-consumer we simulated the number of income levels to be used in the analysis: 8 ip $=0.70) .7(p=0.06), 6(p=0.06), 5(p=0.06)+4(p=0.06)$ or $3(p=0.06)$. The probability distribution used here is an approximation of the last column in Kalpteyn's Table 1 (1977, p. 74). For pseudo-consumers with income levels missin: we ramdomly determined which levels were omitled from the analysis. For the simulation a sample size of 1000 pseudo-consumers was usied.: The :ollowing guantilits were computed for every pscudo-consumer:

\footnotetext{
'Howeser. it: a simulation run where the incoutle intersal wats DI. 5000 - 50000 this different

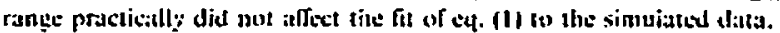

ift transpirat thall wift this :ample sizt a difterent statting number in th= rondo: number

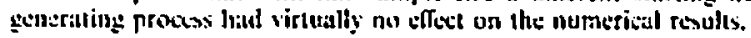


T:abl: 1

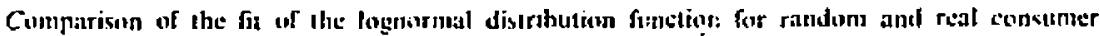
incorsc dara.

\begin{tabular}{|c|c|c|c|c|}
\hline & (I) & $|2|$ & $: 31$ & 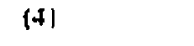 \\
\hline & $\begin{array}{l}\text { Incanicleseds } \\
\text { randingly } \\
\text { dravin }\end{array}$ & 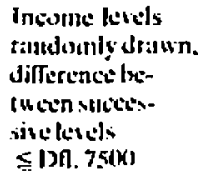 & $\begin{array}{l}\text { incomeleveds } \\
\text { fintided by } \\
\text { etal Ditteh }=11 \text {. } \\
\text { stmers }(197 \$)^{*}\end{array}$ & $\begin{array}{l}\text { Inetumelesels } \\
\text { presided by } \\
\text { teal Dutclicon. } \\
\text { sumers (1455)" }\end{array}$ \\
\hline 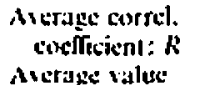 & $0.9(1,0.03)^{n}$ & $0.47(0.02]$ & $0.97(0.04)$ & $0, \% k(0,02)$ \\
\hline $\begin{array}{l}\text { Mí } \\
\text { Merage standard }\end{array}$ & {$[(1.34\{(1\} .12)$} & $10.3 x_{1}(1,1 \geq 1$ & $0.75(0.3(3)$ & $9.75(0 . .34)$ \\
\hline 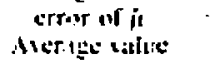 & 0..2R:(1).02) & (1.).3.10.(1) & $(1,1), 3,(1,6,3)$ & $0.11 \geq(0 .,(1)\}$ \\
\hline $\begin{array}{l}\text { of } \overline{7} \\
\text { Hrerage standard }\end{array}$ & $0.3 \times(i) .101$ & $(13)(0)(8)$, & $(0.4 .3(0) .03)$ & $0 .+11(0.17)$ \\
\hline 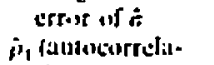 & $(0.05 ;(1.11,3)$ & {$\left[0_{0}(4) \mid 11.112\right)$} & $11.14+0 .(1.3)$ & $00_{t}(1,3 \mid(1,0) \geq\}$ \\
\hline 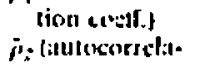 & $-0 .(1590.36)$ & $11,012 i(1) .35)$ & $(1.14(0) .35)$ & $(1.0 .2(0) .37)$ \\
\hline [icon cortl.] & $-(1,04(1), 37)$ & $0,13,3(0,39)$ & $0.03(1) .39)$ & $(11)(0) .39)$ \\
\hline $\begin{array}{l}\text { Reniduit } \\
\text { iarialnte: }\end{array}$ & (1). & 0.6)iy & $11 \times 1 \times 18$ & {$[1.01030$} \\
\hline$n$ & $I(x)$ & $|(x)|$ & ry & $17+4 k$ \\
\hline
\end{tabular}

the mahtiple correlation coeficient $R$ (unsupatred), $j, \dot{r}$. standard error of $j$. standard error of $\dot{\sigma}_{.} \dot{\rho}_{1}$ and $\dot{p}$. . They correspond with the quantities given by Kapteyn in his Table 2 (1977. p. 75). Here $\dot{p}_{2}$ and $\hat{p}_{2}$. Kapteyn $(19 \% 7$. pp. 71 . 72). are estimated atutocorrelation cosficients used to lest the lintarity of the model. For all pseudo-consumers in the samplu. allerages for these quantitus were computed. These are preiented in column 1 of table $t$.

In the procedure for drawing incomes randomly. described above, difierences between successive income levels can become unrealistically large. for example, one of the pseudo-respondents had DN. 15000 as his lowest income level (which would correspond to 'very bad" in Van Pratag and Kaptcyn's questiundaire). while his nexl lowest level (corresponding to "bind") was Df. 27000. Another psetrdo-consumer has ats his highest two Ievels: Dil. 36000 ("good) and DN. 49000 ("sucelleni"). Since such differences are very unlikely in practice, as well as carrying out a simulation in which there was no upper limit for the intervals belween successive income levels. we did a simulation in which the maximum perinissible finit for these intervals was Df. 7500. The results for this simulation are given in column 2 of table 1. 


\section{Discussion of the results}

Table I presents the results from the randon income data next to the corresponding statisties oblained by Van Praig and Kapteyn in their two must recent studies for the Netherlands [Kapteyn (1977, table 2, p. 75)]. The samples used in the latter studies are deseribed by Kapteyn (p. 84 ). ${ }^{3}$ Considering $k$, it appears that the fit of the lognormal modei is practically as gond for the simulated data as for the real data. This is also reflected in the very small standard deviations of $\dot{j}$ and $\dot{\sigma}$ in the simulated data which are in the same order of magni.ude as in the real data. The estimated autocoritlation couflicients are atso of the same order of magnitude fabsolute vatues). The values of $\dot{j}$ and $\dot{\sigma}$ do not measure the fit of the lognormal model. but indicate how ;ell the income interval chosen reflects realtily. By comparing their values in the simulation with those from the teal study this appeatrs to be salisfaclo:y.

The somewhat larger residsul variance in the simulated data compared with the real data is due to the assumed homogeneity of consumers in the simulation. i.e. with respect to the interial from which the incomes are drawn.+ In the simulation siudy escry pseudo-consumer was assumed to have the whole range from Dn 15000.50000 as his reference income range, but in reality some consumers weuld have a reference range of, for example. Dn. 15010-35006; (such consumers consider Dn. 35000 to be ill excellent uncone): oller consumers would liave a reference ralige from Dil. 30000-50100, and so on. For such individuals the variance of the dependent variabl: in the regression equation (1). and genterally $s^{2} 100$, will be smaller than when the reference income range is D: 15000.50000 . In a simulation run with a mixure of 500 consumers drawing their income levels from the interval DA. 155010-35000. and 501) ronsumers drawing their income levels from lie interval Df. 30000-50000. $s^{2}$ turned out to be as low as 0.0033 .

The uniform órawing interval also results in a relatively stmall simple standard deviation of $i$ in the simulation sudy: 0.12 compared $v$ th 0.36 and 0.34 in the real dati. In the "mixed" simulation just mentiored this sample standard deviation increased to 0.25 .

In spite of the very unrealistic jumps in income levels that ociur, the fit of the !ognormal model in coltimn 1 of table 1 is very good. Column 2 of the tablt: shows that the fil improves even more when the most extreme differences are removed. All additional simulation run showed that when the differences between stecessive income levels are further testricled, i.e., 10 Dil. 5000. $\bar{R}$ betomes as high as 0.98 . Since this type of restriction las the eflect

\footnotetext{
Jor reawns of concistuess only these two sludits by Van Praug and hanteyn ate reterrad lo laers. Iloweres, llie reselts are 1ypical for lhuir complate set of six studies.

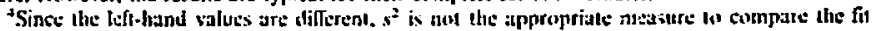

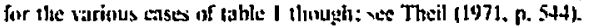


"If equatizin! the incoillic intersals. it appears that any tendency for the constmer to provide ecjual incons: intervals - which soems on be very natural in a task like this - increatses $k$ in l'an Pratag and Kapteyns test. It should be

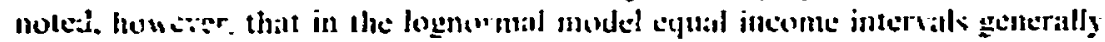
do not correspend witi equal tetility intervals. that are the bassis of vall

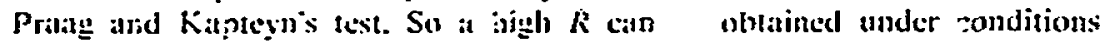
lhall are very dicergent from llousc assomed ey Van Pratag and Kapteyn. Since the expected income intervils alce ceptral, illso in the simulation of the unfestricted model the assumplom of ecpual utility intermals is violated. though.

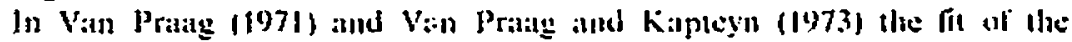
lognormal model is judged on the basis of tic quantities $R, p_{1}$ and $\dot{p}_{2}$ given

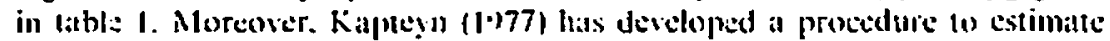
how muth of the residual varjintes st is callsed by rounding-off etrors findicated as: ic $\mathrm{c}^{2}$ ) and how much is accounted for by ollas lypes of error. including specification errors. It is fatorable for the lognormal model when

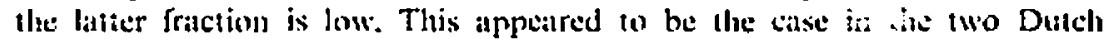
studies of 197t and 1975. Wilere Kapleyn estimated this fatition to be 0.06 and 0.07. respectively:

We did not bate at our disp̧osal the numerical procedure for estimating ! $0^{2}$. but thanks to Kapteyns hind cooperation we were able to process the income levets of 300 of our pieudu-consuners using his method. It appeared that thest random datta also easily pissed this specifteation test: the part of $s^{2}$ duc to specification and other erress was testimated to be as low as 0.04 .

\section{Conclusion}

II appears that in the procedure used by Van Pratag and Kapteyn to test the lognormality loypothesis random data produce the sime fi: as the income dala actually collected from real consumers. If the consumers that were incerviewed would have responded by dividing their refereme income range randomly into nine intervals. the resulting $k$ would hate been of the same order of magnitude ais the values acoually found by Van Prases and Kapteyn. Any tendency for llat consumer to divide the income range into intervals of approximalely equal length would further incrcale $K$. Such sandon data clearly : iolate the asisumption of equal utility intervals which is the basis of

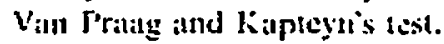

fts a constequence the results. reported witl respect to the fit of the lognormal model obtainet: by this test. exen althougl they are based on tice data frem more than 12000 constamers proside no substantial sulport lor this model.

On the other hand. the simulation results reported in this paper do not imply lhal Van Pratin and Kapteyn's results are at variance with the 
lognomal model. A test in which random data produce a multiple correlation cosfficient of 0.9 ? simply cannot he expecled to provide conclusive evidence either to stpport or to refute at model. Furthermore it is possible thall the assumption of equal utltity intersals in the income data provided by consumers is wrong. This would cemove the rationale behind Van Prata and Kapteyn's test and make !heir results irrelesant with respect to the question whether or not the lognotmal noded is correct. Van Pratg and kapteyn did not test this assumption. They merely shen that equal utility intervals will oceur when the respondent minimizes aserage intecuracy fas derimed by the authors). The assumption implies that the income levels mentioned by the respondent are independent from the speciñc verbal statements (such as "excellent: "good". etc.) in lle gltestionnatire. This is not very plausible: it secms uniticly that a respondent would stitic the sane income levels if a different set of nine verbal qualifications would be used.

If it is at all possible to lest the lognormal model tusing statements mide by respondents in al survey. a more claborate research procedure is required. The effort should be directed towards obtaining more information from eacls respondent, instead of to increalse the number of tespondents in the sample to thousands of individuals. For example, it should be ascertained whether at person is consistem with the noded when eralluatling "new" income levels (i.t.". levels not used to estimale his welfare lunction parametersl and when eraluating and comparing income differences. The sensitivity of the eslimatles to different verbal statements in the yutestionuaire needs to be checked and it should be examined if a person produces the same welfare functions when intervicued on different oceasions. Of courst, llis requires a more compliealted inlerviewing: it would se difficull to colled all this information by means of a postal survey. $A$ aredel that makes such specific assumptions ahout indisidual welfare eralu:tion requires specific lesting procedures to test its validitity.

\section{ReTerences}

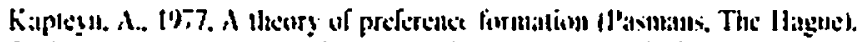

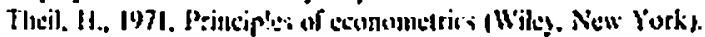

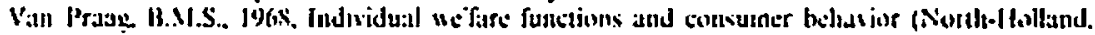
Amisterditms.

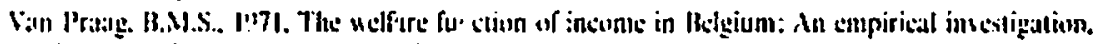
liuruptim l:conounic Kowiew. Spring. $33736 \%$.

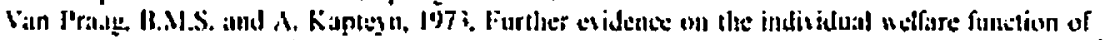

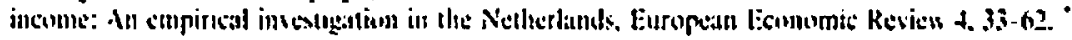

